\title{
ASESMEN PEMBELAJARAN BERBASIS PORTOFOLIO DI SEKOLAH
}

\author{
Oleh \\ Wahyudi $^{1}$
}

\begin{abstract}
Abstrak: Otonomi daerah membawa konsekuensi adanya restrukturisasi kelembagaan pemerintah, termasuk di bidang pendidikan. Manajemen berbasis sekolah (MBS) merupakan bentuk alternatif pengelolaan sekolah dalam rangka desentralisasi pendidikan yang ditandai adanya kewenangan pengambilan keputusan yang lebih luas di tingkat sekolah, partisipasi masyarakat yang lebih tinggi dalam kerangka kebijakan pendidikan nasional. MBS bertujuan untuk meningkatkan efisiensi, mutu, dan pemerataan pendidikan.
\end{abstract}

Kata-kata Kunci: Asesmen Pembelajaran, Portofolio, Hasil Belajar.

\section{A. Pendahuluan}

Penggunaan istilah penilaian, saat ini lebih dikenal dengan kata asesmen yang artinya suatu proses untuk mengambil keputusan dengan menggunakan informasi yang diperoleh melalui pengukuran hasil belajar, baik yang menggunakan instrumen tes maupun non tes. Asesmen (penilaian) adalah memberikan nilai tentang kualitas sesuatu. Tidak hanya sekedar mencari jawaban terhadap pertanyaan tentang apa, tetapi lebih diarahkan kepada menjawab pertanyaan bagaimana atau seberapa jauh sesuatu proses atau suatu hasil yang diperoleh seseorang atau suatu program.

Kurikulum tingkat satuan pendidikan (KTSP) menggunakan prinsip belajar tuntas (mastery learning). Setiap siswa harus menguasai standar kompetensi yang telah ditentukan sebagai komponen minimal. Bagi siswa yang telah menguasai lebih cepat dari yang lain, mereka belajar kompetensi berikutnya (akselerasi belajar). Siswa yang masih kurang baik penguasaan kompetensinya mengikuti program pengayaan. Dan yang gagalharus mengikuti program remidial. Portofolio sebagaisalah satu cara penilaian harus mampu mengungkap pencapaian standar kompetensi dan kompetensi dasar setiap siswa. Karena itu penilaian, termasuk portofolio sebaiknya dikembangkan secara individual

\footnotetext{
${ }^{1}$ Wahyudi adalah dosen Jurusan Ilmu Pendidikan FKIP-UNTAN Pontianak
} 


\section{B. Pengertian Tes, Pengukuran dan Asesmen Pembelajaran}

Istilah tes telah cukup dikenal dikalangan pendidik maupun masyarakat sehingga bukan merupakan hal yang aneh dan hampir setiap setiap orang pernah mendengar, membicarakan, atau bahkan pernah mengikuti tes. Sejak anda mema-suki sekolah mulai dari sekolah dasar (SD), anda sudah sering mendengar istilah tes. Bahkan kata tes sudah sedemikian memasyarakatnya di dalam wacana pendidikan kita sehingga seakan-akan tidak pernah ada pendidikan tanpa tes. Namun apabila ditanya mengenai apakah sebenarnya tes itu, kiranya tidak banyak orang yang benar-benar memahami dan dapat menjelaskannya secara baik.

Dalam makalah ini, istilah "tes" diartikan sebagai suatu pertanyaan atau tugas atau seperangkat tugas yang direncanakan untuk memperoleh informasi ten-tang atribut pendidikan atau psikologik tertentu dan setiap butir pertanyaan atau tugas tersebut mempunyai jawaban atau ketentuan yang dianggap benar, dan apabila tidak memenuhi ketentuan tersebut, maka jawaban Anda dianggap salah, (Zainul, A. dan Mulyana, A., 2007: 3). Dari pengertian tersebut di atas, karakteristik tes yaitu, (1) tes dapat berbentuk pertanyaan, (2) tes dapat berbentuk tugas yang harus dikerjakan oleh peserta tes, (3) tes digunakan untuk memperoleh informasi tentang atribut pendidikan atau psikologik, (4) tes menghendaki adanya jawaban atau cara mengerjakan yang benar.

Tes juga dapat diartikan sebagai seperangkat tugas yang harus dikerjakan atau sejumlah pertanyaan yang harus dijawab oleh peserta didik untuk mengukur tingkat pemahaman atau penguasaan terhadap cakupan materi yang dipersyaratkan dan sesuai dengan tujuan pengajaran tertentu (Poerwanti, E. 2008: 1). Jadi dengan dua definisi di atas makin jelaslah hakekat tes yaitu sebagai suatu alat untuk mengumpulkan informasi tentang ketercapaian tujuan pendidikan atau tujuan pembelajaran. Karena itu setiap butir tes harus dapat dirumuskan secara akurat sehingga tidak menyebabkan peserta tes tidak dapat mengetahui secara akurat informasi yang diminta oleh butir soal tersebut atau jangan sampai butir tes justru bermakna ganda sehingga menyebabkan peserta tes sukar memberikan jawaban yang diminta.

Untuk memperoleh informasi tentang atribut pendidikan atau psikologik tertentu tidak hanya dilakukan dengan instrumen tes, tetapi juga dapat berbentuk non tes; wawancara dan kuesioner, skala sikap, observasi, atau sosiometri.

Secara garis besar telah kita pahami definisi tes, selanjutnya kita kaji definisi pengukuran. Pengukuran diartikan sebagai sebagai suatu proses dimana kita mengenakan angka-angka kepada barang atau gejala-gejala berdasarkan aturan-aturan tertentu (Raka Joni, 1994: 7). Pendapat yang lebih lengkap dikemukakan oleh Asmawi Zainul dan Noehi Nasoetion (1994: 5), 
bahwa pengukuran diartikan sebagai pemberian angka kepada suatu atribut atau karakteristik tertentu yang dimiliki oleh orang, hal, atau objek tertentu menurut aturan atau formulasi yang jelas. Misalkan untuk mengukur tinggi atau berat seseorang dengan mudah kita memahami, karena aturannya telah diketahui secara umum. Tetapi untuk mengukur bakat dan kecerdasan seseorang jauh lebih kompleks dan tidak semua orang memahaminya. Dalam kegiatan seperti ini sudah barang tentu aturan dan formulasinya tidak sederhana. Kegiatan pengukuran menjadi lebih komplek bila akan mengukur karakteristik psikologik seseorang: kecerdasan, kematangan, atau kepribadian. Demikian halnya dengan pengukuran dalam bidang pendidikan yang mengukur atribut peserta didik: penguasaan materi, kemampuan dalam melakukan keterampilan tertentu. Pengukuran pendidikan merupakan merupakan pekerjaan profesional guru, tutor, atau instruktur. Tanpa kemampuan melakukan pengukuran pendidikan, seorang guru atau tutor tidak akan mengetahui persis keadaan siswa dan keberhasilan dalam mengelola pembelajaran.

Dari definisi pengukuran yang dikemukakan di atas, terdapat dua karakteristik pengukuran yang utama, yaitu (1) penggunaan angka atau skala tertentu, dan (2) menurut suatu aturan atau formula tertentu. Karena pengukuran menggunakan angka atau skala tertentu, maka untuk lebih memahami penggunaan angka atau skala tersebut maka guru atau tutor perlu mengetahui karakteristiknya.

Skala atau angka itu dapat diklasifikasikan ke dalam empat kategori, yaitu (1) angka nominal, yaitu angka yang bersifak kategorikal, misalnya bila sebutir soal dapat dijawab benar benar oleh siswa atau warga belajar, maka ia mendapat skor 1 (satu), sedangkan bila jawabannya salah maka ia memperoleh skor 0 (nol). (2) angka ordinal yaitu angka yang menunjukkan adanya urutan, tanpa mempersoalkan jarak antar urutan tersebut. Misalnya, angka yang menunjuk urutan ranking siswa atau warga belajar dalam suatu mata pelajaran tertentu. Siswa yang memperoleh ranking 1 (satu) tidak berarti dua kali lebih pandai dari siswa ranking 2 (dua). Jarak kepandaian siswa ranking 1 dengan ranking 2 tidak sama dengan jarak kepandaian siswa ranking 2 dengan ranking 3, dan seterusnya. (3) skala atau angka interval yaitu angka yang menunjukkan adanya jarak yang sama dari angka yang berurutan. Misalnya angka $\mathrm{Km}$ untuk mengukur jarak. Jarak antara $\mathrm{Km} 1$ dengan $\mathrm{Km} 2$ sama dengan jarak antara $\mathrm{Km} 3$ dengan Km4, dan seterusnya. (4) Skala atau angka rasio, yaitu angka yang memiliki semua karakteristik angka atau skala yang terdahulu dan ditambah dengan satu karakteristik lagi, yaitu memiliki nol mutlak. Misalnya tinggi badan seseorang, bila ada tinggi badan manusia $0 \mathrm{~cm}$, maka tinggi tersebut tidak mempunyai makna. Demikian pula dengan berat badan manusia, angka 0 (nol) tidak bermakna. 
Selanjutnya, karakteristik kedua dari pengukuran adalah menurut suatu aturan atau formula tertentu. Salah satu aturan yang digunakan untuk pengukuran dapat menggunakan pendekatan penilaian acuan norma (PAN) dan penilaian acuan patokan (PAP). Pendekatan acuan norma merupakan sistem penilaian yang didasarkan pada nilai sekelompok siswa dalam satu proses pembelajaran didasarkan pada tingkat penguasaan di kelompok itu. Artinya pemberian nilai mengacu pada perolehan skor di kelompok itu. Sedangkan penilaian acuan patokan yaitu suatu cara menentukan kelulusan seseorang dengan menggunakan sejumlah patokan. Bilamana seseorang telah memenuhi patokan tersebut ia dinyatakan berhasil. Tetapi bila seseorang belum memenuhi patokan, ia dinyatakan gagal atau belum menguasai bahan tersebut.

Setelah dibahas pengertian tes dan pengukuran, maka selanjutnya kita pahami pengertian asesmen (penilaian). Asesmen dapat didefinisikan sebagai suatu proses untuk mengambil keputusan dengan menggunakan informasi yang diperoleh melalui pengukuran hasil belajar, baik yang menggunakan instrumen tes maupun non tes. Dikemukakan oleh Asmawi Zainul dan Agus Mulyana (2007: 7) bahwa, asesmen (penilaian) adalah memberikan nilai tentang kualitas sesuatu. Tidak hanya sekedar mencari jawaban terhadap pertanyaan tentang apa, tetapi lebih diarahkan kepada menjawab pertanyaan bagaimana atau seberapa jauh sesuatu proses atau suatu hasil yang diperoleh seseorang atau suatu program. Hal senada dikemukakan oleh Nana Sudjana (1990: 3) asesmen atau penilaian adalah proses memberikan atau menentukan nilai kepada objek tertentu berdasarkan suatu kriteria tertentu .

Proses pemberian nilai tersebut berlangsung dalam bentuk interpretasi yang di akhiri dengan judgment. Interpretasi dan judgment merupakan tema asesmen/penilaian yang mengimplikasikan adanya suatu perbandingan antara kriteria dan kenyataan dalam konteks situasi tertentu. Atas dasar itu maka dalam asesmen/penilaian selalu ada objek/program, ada kriteria dan ada interpretasi dan judgment.

Dengan demikian Asesmen/Penilaian diartikan sebagai suatu proses untuk mengambil keputusan dengan menggunakan informasi yang diperoleh melalui pengukuran hasil belajar yang menggunakan instrumen test maupun non test.

Asesmen hasil belajar adalah proses pemberian nilai terhadap hasilhasil belajar yang dicapai siswa dengan kriteria tertentu. Hal ini mengisyaratkan bahwa objek yang dinilai adalah hasil belajar. Hasil belajar siswa pada hakekatnya adalah perubahan pengetahuan atau pemahaman dan tingkah laku. Karena itu dalam penilaian hasil belajar, peranan kompetensi dasar (KD) yang berisi rumusan kemampuan dan tingkah laku yang diinginkan dikuasai siswa menjadi unsur penting sebagai dasar dan acuan 
penilaian. Penilaian proses belajar adalah upaya memberi nilai terhadap kegiatan pembelajaran yang dilakukan siswa/warga belajar dan guru/tutor dalam mencapai tujuan-tujuan pembelajaran. Dalam penilaian dilihat sejauh mana keefektifan dan efisiennya dalam mencapai tujuan pengajaran atau perubahan tingkah laku siswa. Penilaian hasil dan proses belajar saling berkaitan, sebab hasil merupakan akibat dari proses.

\section{Tujuan Asesmen Pembelajaran}

Asesmen atau penilaian dilaksanakan mempunyai beberapa tujuan. Sebagaimana dikemukakan oleh Arikunto (1995: 9) bahwa tujuan dan fungsi penilaian meliputi, (1) penilaian berfungsi selektif, (2) penilaian berfungsi diagnostik, (3) penilaian berfungsi sebagai penempatan, dan (4) penilaian berfungsi sebagai pengukur keberhasilan. Tidak berbeda dengan pendapat di atas, Nana Sudjana (1990: 3) mengemukakan bahwa fungsi dan tujuan asesmen/penilaian adalah sebagai berikut, (1) mendeskripsikan kecakapan belajar para siswa, (2) mengetahui keberhasilan proses pendidikan dan pengajaran, (3) menentukan tindak lanjut hasil penilaian, (4) memberikan pertanggungjawaban dari pihak sekolah kepada stakeholders, (5) sebagai dasar umpan balik bagi perbaikan proses belajar-mengajar.

Mendeskripsikan kecakapan belajar siswa, maksudnya adalah asesmen atau penilaian untuk mengetahui kelebihan dan kekurangan kecakapan siswa dalam berbagai bidang studi atau mata pelajaran yang ditempuhnya. Dengan pendeskripsian kecakapan siswa dapat diketahui pula posisi kemampuan siswa dibandingkan denbgan siswa lainnya.

Mengetahui keberhasilan proses pendidikan dan pengajaran di sekolah, yakni untuk mengetahui seberapa jauh keefektifannya dalam mengubah tingkah laku para siswa ke arah tercapainya tujuan kurikulum atau tujuan pendidikan yang ditetapkan. Keberhasilan penddikan dan pengajaran penting artinya sebagai upaya memanusiakan manusia atau membudayakan manusia, dalam hal ini para siswa agar menjadi manusia yang berkualitas dalam aspek intelektual, sosial, emosional, moral, dan keterampilan.

Menentukan tindak lanjut hasil penilaian, yakni melakukan perbaikan dan penyempurnaan dalam hal program pendidikan dan pengajaran serta strategi pelaksanaannya. Kegagalan siswa dalam mencapai prestasi belajar tidak dipandang sebagai kekurangan pada diri siswa sematamata, tetapi bisa disebabkan oleh program pengajaran, atau kesalahan strategi pembelajaran, atau dapat juga disebabkan kurang tepatnya dalam memilih alat bantu pembelajaran.

Memberikan pertanggungjawaban (accountability) dari pihak sekolah kepada pihak-pihak yang berkepentingan. Pihak yang dimaksud 
meliputi pihak pemerintah, masyarakat, dan orang tua siswa. Dalam mempertanggungjawabkan hasil-hasil yang dicapai, sekolah sekolah memberikan laporan berbagai kekuatan dan kelemahan pelaksanaan sistem pendidikan dan pengajaran serta kendala yang dihadapi.

Umpan balik bagi perbaikan proses pembelajaran yaitu perbaikan dalam hal melakukan proses pembelajaran, strategi pembelajaran, ataupun perencanaan pembelajaran.

\section{Pengertian Portofolio}

Dalam bidang pendidikan dan pengajaran, istilah portofolio relatif masih baru dan belum dikenal luas. Akan tetapi seiring dengan diberlakukannya Kurikulum Tingkat Satuan Pendidikan (KTSP), istilah portofolio sering menjadi bahan diskusi di kalangan guru atau kepala sekolah. Portofolio dapat diartikan sebagai wujud benda fisik, sebagai suatu proses sosial pedagogis, maupun sebagai adjective (Budimansyah, 2002:1). Sebagai suatu wujud benda fisik, portofolio itu adalah bundel, yakni kumpulan atau dokumentasi hasil pekerjaan peserta didik yang disimpan pada suatu bendel. Sebagai suatu proses sosial pedagogis, portofolio adalah collection of learning experience yang terdapat di dalam pikiran peserta didik baik yang berujud pengetahuan, keterampilan, maupun nilai dan sikap. Adapun sebagai suatu adjective, portofolio sering kali disandingkan dengan konsep lain, diantaranya dengan konsep pembelajaran maka dikenal istilah pembelajaran berbasis portofolio. Jika disandingkan dengan konsep penilaian dikenal istilah penilaian berbasis portofolio. Hal senada dikemukakan oleh Surapranata dan Hatta (2004) bahwa portofolio dapat diartikan sebagai kumpulan hasil belajar atau karya peserta didik yang menunjukkan usaha, perkembangan, prestasi belajar peserta didik dari waktu ke waktu dan dari satu mata pelajaran ke mata pelajaran yang lain. Portofolio secara sederhana dapat juga diartikan sebagai bukti-bukti pengalaman belajar peserta didik yang dikumpulkan sepanjang waktu, misalnya satu semester atau satu tahun.

Dalam pembahasan disini, portofolio merupakan suatu kumpulan pekerjaan peserta didik dengan maksud tertentu dan terpadu yang diseleksi menurut panduan-panduan yang ditentukan.

\section{E. Bentuk Portofolio}

Terdapat beberapa bentuk atau variasi dalam portofolio yang digunakan. Cole, Ryan \& Kick (1995) mengklasifikasi bentuk portofolio terdiri dari, (1) tinjauan proses (prosess oriented) dan (2) tinjauan hasil (product oriented). Portofolio proses menunjukkan tahapan belajar dan 
menyajikan catatan perkembangan peserta didik dari waktu ke waktu. Portofolio proses adalah portofolio yang menekankan pada tinjauan bagaimana perkembangan peserta didik dapat diamati dan dinilai dari waktu ke waktu. Pendekatan ini lebih menekankan pada bagaimana peserta didik belajar, berkreasi, termasuk mulai dari draf awal, bagaimana proses awal itu terjadi, dan tentunya sepanjang peserta didik dinilai. Hal yang dinilai mencakup kemampuan awal, di tengah, atau di akhir suatu pekerjaan yang dilakukan peserta didik. Portofolio proses menunjukkan kegiatan pembelajaran untuk mencapai standar kompetensi, kompetensi dasar dan sekumpulan indikator yang dituntut oleh kurikulum, dan menunjukkan semua hasil dari awal sampai akhir dalam kurun waktu tertentu. Guru menggunakan portofolio proses untuk menolong peserta didik mengidentifikasi tujuan pembelajaran, perkembangan hasil belajar dari waktu ke waktu, dan menunjukkan pencapaian hasil belajar.

Portofolio ditinjau dari hasil (product oriented) adalah portofolio yang menekankan pada tinjauan hasil terbaik yang telah dilakukan peserrta didik, tanpa memperhatikan bagaimana proses untuk mencapai evidence itu terjadi. Portofolio semacam ini bertujuan untuk mendokumentasikan dan merefleksikan kualitas prestasi yang telah dicapai. Penilaian terhadap portofolio hasil biasanya memerlukan peserta didik untuk mengkoleksi semua pekerjaan mereka, dimana pada suatu saat mereka harus menunjukkan evidence yang terbaik. Secara umum portofolio hasil (product) melihat dari sisi tampilan terbaik (shows portfolio) dan portofolio dokumentasi (documentary portfolio) menilai dokumentasi siswa yang terbaik.

\section{F. Penilaian Portofolio}

Sebagaimana telah dikemukakan di atas, bahwa Asesmen/Penilaian diartikan sebagai suatu proses untuk mengambil keputusan dengan menggunakan informasi yang diperoleh melalui pengukuran hasil belajar yang menggunakan instrumen test maupun non test. Sedangkan penilaian portofolio merupakan penilaian berkelanjutan yang didasarkan pada kumpulan informasi yang menunjukkan perkembangan kemampuan peserta didik dalam satu periode tertentu. Informasi tersebut dapat berupa karya peserta didik dari proses pembelajaran yang dianggap terbaik oleh peserta didik .

Penilaian portofolio pada dasarnya menilai karya-karya siswa secara individu pada satu periode untuk suatu mata pelajaran. Akhir suatu periode hasil karya tersebut dikumpulkan dan di nilai oleh guru dan peserta didik. Berdasarkan informasi perkembangan tersebut, guru dan peserta didik sendiri dapat menilai perkembangan kemampuan peserta didik dan terus 
melakukan perbaikan. Dengan demikian, portofolio dapat memperlihatkan perkembangan kemajuan belajar peserta didik melalui karyanya,

\section{G. Prosedur Penilaian Portofolio}

Tahapan yang perlu dilakukan dalam melaksanakan penilaian portofolio sebagai berikut;

1. Jelaskan kepada peserta didik bahwa penggunaan portofolio, tidak hanya merupakan kumpulan hasil kerja peserta didik yang digunakan oleh guru untuk penilaian, tetapi digunakan juga oleh peserta didik sendiri.

2. Tentukan bersama (guru dan peserta didik) portofolio apa saja yang akan dikumpulkan.

3. Kumpulkan dan simpanlah karya-karya tiap peserta didik dalam satu map atau folder di rumah atau loker masing-masing di sekolah.

4. Berilah tanggal pembuatan pada setiap bahan informasi perkembangan peserta didik. sehingga dapat dilihat perbedaan kualitas dari aktu ke waktu.

5. Tentukan kriteria penilaian portofolio dan bobotnya kepada peserta didik.

6. Minta peserta didik menilai karyanya secara berkesinambungan.

7. Apabila hasil yang dicapai belum memuaskan atau belum mencapai standar ketuntasan minimal (SKM), maka peserta didik diberi kesempatan untuk memperbaiki.

8. Jadualkan pertemuan untuk membahas portofolio, bila memungkinkan, undang orang tua untuk mendiskusikan hasil yang dicapai peserta didik/warga belajar.

\section{H. Penutup}

Asesmen pembelajaran berbasis portofolio memerlukan keseriusan dan ketekunan para guru dan siswa. Portofolio sebagai pendekatan baru dalam penilaian memiliki kelemahan disamping kelebihannya. Kelemahan yang terjadi pada portofolio antara lain, (1) portofolio mungkin tidak merupakan karya siswa sendiri, tetapi juga ada bantuan dari teman, saudara, dan orang tua, (2) memerlukan waktu dan tenaga bagi guru untuk memilih tugas portofolio, menyususn portofolio bersama siswa, dan mengoreksi portofolio, (3) memerlukan tempat untuk mengoleksi dan menyimpan portofolio siswa dengan baik.

Sebagai upaya mengatasi kelemahan dimaksud, guru harus merencanakan, melaksanakan, dan memantau proses penyususnan dan penilaian portofolio secara konsisten. Guru harus menyediakan waktu tambahan untuk mempersiapkan tugas kepada siswa, memberi nilai hasil karya siswa,dan memberikan umpan balik terhadap hasil yang dicapai masing-masing individu siswa. Dan diupayakan melibatkan siswa dalam menyimpan, menata, serta mengarsipkan berkas-berkas siswa itu sendiri. 


\section{DAFTAR REFERENSI}

Arikunto, S. (1998). Dasar-dasar Evaluasi Pendidikan. Jakarta: Bumi Aksara.

Budimansyah, D. 2002. Model Pembelajaran dan Penilaian Portofolio. Bandung: PT Genesindo.

Cole, D.J., Ryan, C.W. \& Kick, F. (1995). Portfolios across the curriculum and beyond, California: Corwin Press.

Depdiknas. (2004). Pedoman Penilaian Dengan Portofolio. Jakarta: Depdiknas-Dirjen Pendidikan dasar.

Depdiknas. (2006). Model penilaian Kelas; Kurikulum Tingkat Satuan Pendidikan Seko-lah Dasar/Madrasah Ibtidaiyah. Jakarta: Depdiknas-Dirjen PMPTK.

Irawan, P., Suciati. \& Wardani. (1994). Teori Belajar, Motivasi, dan Keterampilan Mengajar. Jakarta: Depdikbud. Dirjen Dikti- Pusat Antar Universitas.

Raka Joni.(!994). Pengukuran dan Penilaian Pendidikan. Surabaya: Karya Anda.

Soekamto, T. \& Winataputra, U.S. (1994). Teori Belajar dan Model-Model Pembelajaran.

Jakarta: Depdikbud. Dirjen Dikti- Pusat Antar Universitas.

Surapranata, S. \& Hatta, M. (2004). Penilaian Portofolio: Implementasi Kurikulum 2004. Bandung: PT Remaja Rosdakarya.

Nasution, N. \& Suryanto, A. (2008). Evaluasi Pengajaran. Jakarta: Universitas Terbuka. 


\section{PERSYARATAN NASKAH UNTUK JURNAL “VIP”}

1. Artekel yang dimuat dalam jurnal ini meliputi tulisan tentang hasil penelitian, gagasan konseptual, kajian dan aplikasi teori, tinjauan kepustakaan, resensi buku baru, dan kajian analitis kritis di bidang Pendidikan.

2. Artikel ditulis dengan bahasa Indonesia/Inggris, panjang 10-15 halaman kertas HVS ukuran A4 spasi ganda, dilengkapi dengan abstrak (50-75 kata) dan katakata kunci. Biodata singkat penulis dicantumkan sebagai catatan kaki pada halaman pertama naskah. Naskah diketik menggunakan pengolah kata MS Word dengan huruf Times New Roman diserahkan paling lambat 1 bulan sebelum penerbitan.

3. Tata cara penyajian kutipan, rujukan, tabel, dan gambar mengikuti ketentuan dalam Pedoman Penulisan Karya Ilmiah. Naskah diketik dengan memperhatikan aturan tentang penggunaan tanda baca dan ejaan yang dimuat dalam Pedoman Umum Ejaan Bahasa Indonesia yang Disempurnakan (Depdikbud, 1987).

4. Artikel (hasil penelitian) memuat:

Judul

Nama Penulis

Abstrak dalam bahasa Indonesia atau bahasa Inggris

Kata Kunci

Pendahuluan (tanpa subjudul, memuat latar belakang masalah dan sedikit tinjauan pustaka, dan masalah/tujuan penelitian)

Metode

Hasil

Pembahasan

Kesimpulan dan saran

Daftar Rujukan (berisi pustaka yang dirujuk dalam uraian saja)

5. Artikel (setara hasil penelitian) memuat:

Judul

Nama Penulis

Abstrak dalam bahasa Indonesia dan bahasa Inggris

Kata kunci

Pendahuluan (tanpa subjudul)

Subjudul

Subjudul

Subjudul

Penutup (atau Kesimpulan dan Saran)

Daftar Rujukan (berisi pustaka yang dirujuk dalam uraian saja)

6. Kepastian pemuatan atau penolakan naskah akan diberitahukan secara tertulis. Penulis yang artikelnya dimuat akan mendapat imbalan berupa nomor bukti pemuatan sebanyak 3 eksemplar setelah membayar kontribusi biaya cetak. 